\title{
THE EFFECT OF POP UP BOOK LEARNING MEDIA AND CRITICAL THINKING ON RESULTS STUDENTS LEARNING IPS CLASS V ELEMENTARY SCHOOL
}

\author{
Echa Surya Kunanti ${ }^{1}$ \\ State University of Medan, Indonesia \\ Email : echasuryakunanti@gmail.com \\ Syarifah 2 \\ State University of Medan, Indonesia \\ Adi Sutopo ${ }^{3}$ \\ State University of Medan, Indonesia
}

\begin{abstract}
The research was aimed are to: (1). Knowing the result social studies of students who were taught using pop up book media were higher than of students who were taught using poster media in class $V,(2)$. Knowing the social studies learning outcomes of students who think critically is higher than the social studies learning outcomes of students who think critically low in class $V,(3)$. Knowing the interaction between the use of pop up book learning media, posters and critical thinking on social studies learning outcomes for class $V$ students. This type of research is a research conducted using a quasi-experimental method. The sample in this study were students of class $V$. The research design used a $2 \times 2$ factorial design with data analysis techniques using two-way analysis of variance (ANAVA). The results of this study indicate that: (1). The results of the Anova 2x2 test are known to have a value of $F=41,048$ with a price of sig $=0.000$, so it can be concluded that the social studies learning outcomes of students taught with pop up book media are higher than those of students who are taught using poster media. (2). The results of the Anova $2 \times 2$ test showed that the value of $F=$ 45,250 with a price of $\mathrm{sig}=0.000$, so it was concluded that the results of the social studies learning who had high critical thinking were higher than the social studies learning outcomes of students who had low critical thinking. (3). The results of the Anova $2 \times 2$ interaction between the use of pop up book learning
\end{abstract}


media, posters and critical thinking on students social studies learning outcomes are known that $F=4,586$ with a price of sig $=0.038$, so it can be concluded that there is an interaction between the use of pop up book, poster and critical thinking learning media on students social studies learning outcomes is proven true.

Keywords: Learning Media, Pop Up Book, Critical Thinking, Social Science Learning Outcomes

\section{A. Introduction}

The achievement of learning objectives contained in the curriculum can be seen from student learning outcomes. Dimyati and Mudjiono (2006:3) learning outcomes are a process to see the extent to which students can master learning after participating in teaching and learning activities, or the success achieved by a student after participating in learning activities marked by certain numbers, letters, or symbols. agreed by the education provider.

Social science (IPS) is one of the subjects of concern because of the low student learning outcomes. Whereas social studies have been taught from elementary to junior high school levels. Hasan, (2014: 41) argues that: "the function of the elementary school social studies curriculum is to form a rational and responsible attitude towards problems that arise as a result of the interaction between humans and their environment". In addition, social studies lessons have a very important role, one of which is that students can apply social studies lessons in everyday social life.

Based on data obtained from UPTD. SD Negeri 13 Pasar Lapan, the average value of social studies learning outcomes from the 2019 to 2020 school year is not satisfactory because it does not reach the specified minimum completeness criteria (KKM). The data above also shows that students social studies learning outcomes are decreasing in the second 
semester of $2019 / 2020$, this is due to the Covid-19 virus outbreak. In the midst of the Covid-19 virus outbreak that is engulfing various countries in the world including Indonesia, the government has issued a policy so that all students at the elementary / junior high / high school level and universities to conduct distance learning using online learning media to break the spread of the Covid-19 virus.

Current conditions require teachers to be more creative in the teaching and learning process, not only conveying material that already exists in the curriculum, but teachers also have to provide education about the COVID-19 virus without causing fear to their students. Not only that, the delivery of material that is not boring and interesting also needs to be done, because the situation and conditions of learning at home using online learning media are certainly different from those in the classroom. The fact is that it is very complicated to face the online teaching and learning process under current conditions, it is necessary to adjust and synergize between teachers, students, and guardians of students so that all materials can be delivered optimally.

Based on field observations, there are many schools in certain areas, especially UPTD. SD Negeri 13 Pasar Lapan teaches online learning cannot be done, this is caused by many factors that do not support one of them, namely more students whose parents do not have communication tools or android mobile phones as the main supporting means to carry out online learning. Under these circumstances, the school took the initiative to conduct offline learning, especially class $V$, namely learning outside the network and making visits to students homes and conducting learning in groups of 5 or 6 people in turn so that students can still carry out face-toface meetings with their teachers but by fulfilling the health protocol to prevent transmission covid 19 virus. 
The selection of the right learning media is a step from the creativity of a teacher so that students are not bored and tired of receiving lessons. Rizky and Bambang (2020:24) learning media are tools that can be used by teachers to convey information to students related to learning so that it is easy to understand. Thus the selection of the right learning media will also clarify the concepts given to students so that students are always enthusiastic about playing an active role and can think critically so that the learning outcomes achieved can be maximized and in accordance with the expected learning objectives.

Bluemel and Taylor (2012:23) suggest the usefulness of pop up book media, which can be useful for developing critical thinking skills. Smith and Szymanski (2013: 18) explain in their research that the main goal of education is to improve students thinking skills to be successful in everyday life. For this reason, higher thinking skills are needed in the form of critical thinking as more than just an ordinary test. Critical thinking is the basis of higher-order thinking, therefore, critical thinking is a very important activity to be developed starting from the basic level

\section{B. Method}

\section{Research Location and Time}

Location this research was conducted at UPTD. SD Negeri 13 Pasar Lapan, Air Putih District, Batu Bara Regency. The research schedule will be carried out in the even semester of 2020/2021 in March-April.

\section{Population and Sample}

The population of this study were students of class V UPTD. SD Negeri 13 Pasar Lapan and UPTD students. SD Negeri 10 Aras, Air Putih District, Batu Bara Regency TA. 2020/2021 each school consists of 2 classes. The samples in this study were students of Class V UPTD. SD 
Negeri 13 Pasar Lapan, Air Putih District, Batu Bara Regency TA. 2020/2021 which is taken by Random Sampling, which determines randomly by drawing a group to be an experimental class whose learning uses pop up book learning media and a group that becomes a control class whose learning uses poster learning media. After doing the lottery, 25 students were selected for class $V a$ as the experimental class, while class $\mathrm{Vb}$ consisted of 25 students as the control class.

\section{Types of research}

The study was conducted using a quasi-experimental method (Quasi Experimental Method) because this research is an experimental research conducted under conditions that do not allow control or not. Manipulating all relevant variables, so that this study only tested directly the effect of an independent variable on the dependent variable and tested the hypothesis of a causal relationship and also the class used for the study was available. The groups studied included the experimental class group using pop up book learning media and the control class group using poster learning media.

\section{Research Instruments}

The instruments used in this study were the students critical thinking ability test instruments and learning outcomes test instruments. Before carrying out the research, a trial was carried out, namely a pre-test with learning outcomes instruments.

The research instrument used to measure students critical thinking skills is a test in the form of an essay (description) and an instrument to measure learning outcomes is a test in the form of multiple choice. To obtain a good research instrument, the steps that must be taken are: 1 . Planning which includes the formulation of the objectives of writing variables and categories to be included in the grid, 2 . Writing questions, 3. 
Editing, namely completing the instrument with instructions and create answer keys, 4. Conduct trials, 5. Analyze test results, 6. Revise (Zainul and Nasution,

\section{Research procedure}

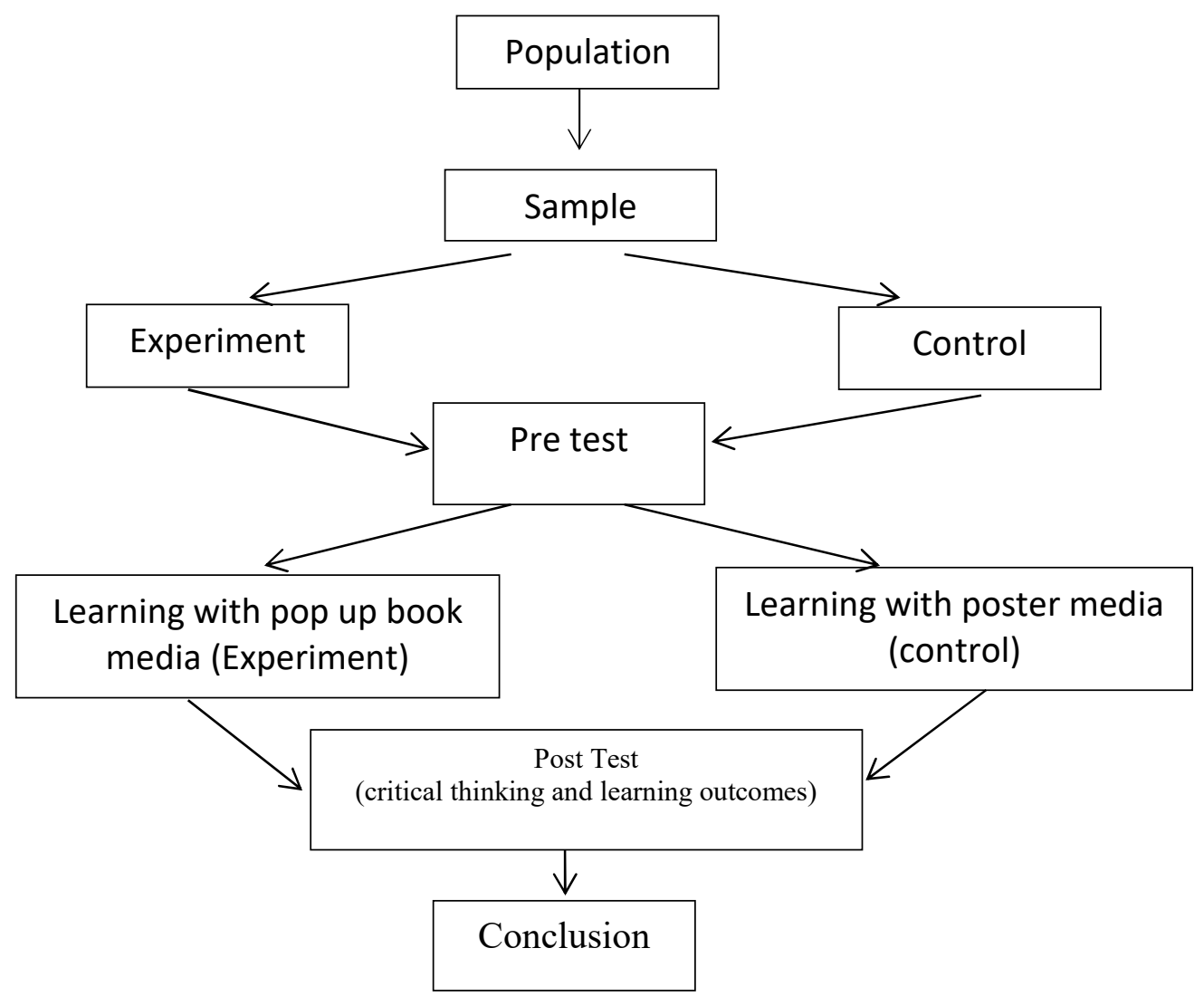

\section{Finding and Discussion}

1. Result

a. Social Studies Learning Outcomes of Students Using Pop Up Book Learning Media

Based on the posttest frequency distribution of social studies 
learning outcomes for classes using pop up books, the histogram can be stated as follows.

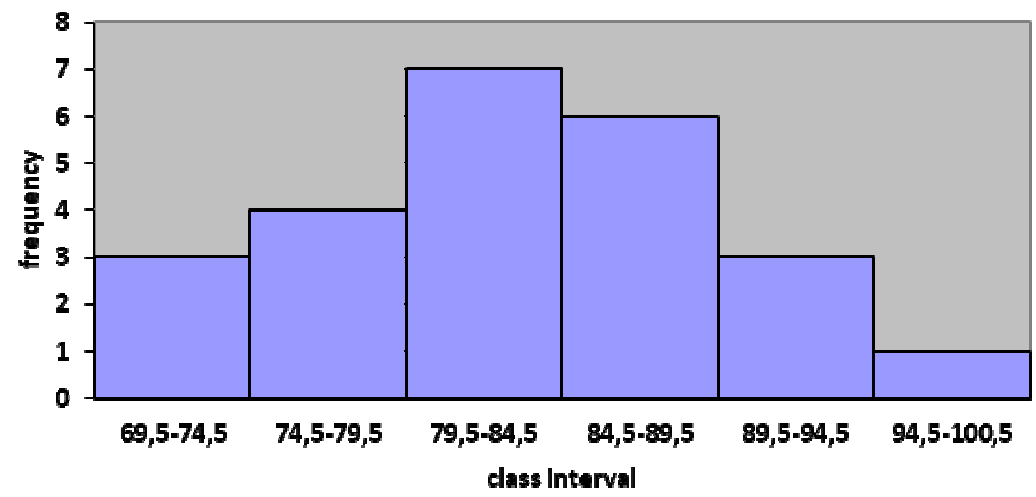

Chart 1. Histogram of Student Learning Outcomes Using Pop Up Book Learning Media

b. Results Learning Social Studies Students Using Poster Learning Media

Based on the posttest frequency distribution data for social studies learning outcomes for students who use poster learning media, the histogram can be stated as follows.

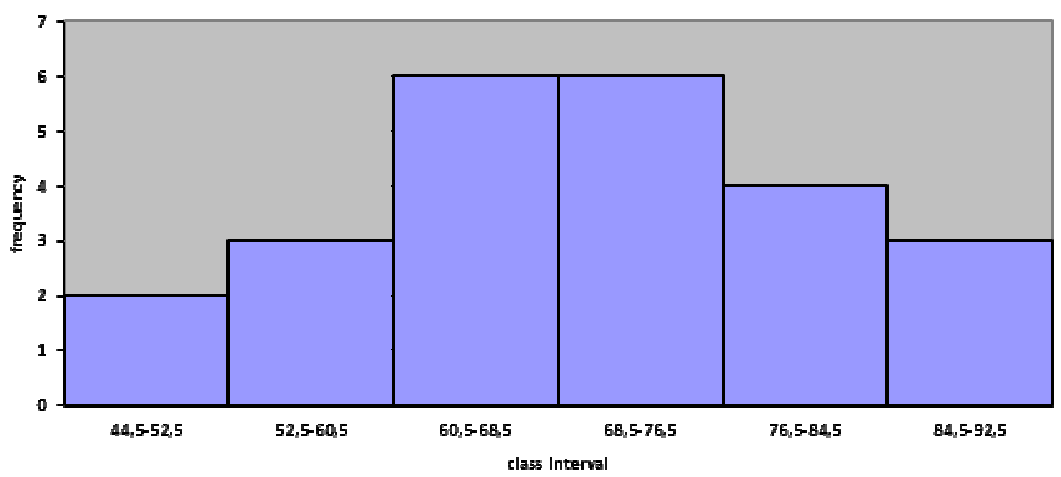

Chart 2. Histogram of Student Learning Outcomes Using Poster Learning Media 
c. Social Studies Learning Outcomes of Students with High Critical Thinking and Low Critical Thinking

Based on the posttest frequency distribution data for social studies learning outcomes of students who use pop up books and posters with high critical thinking, the histogram can be stated as follows.

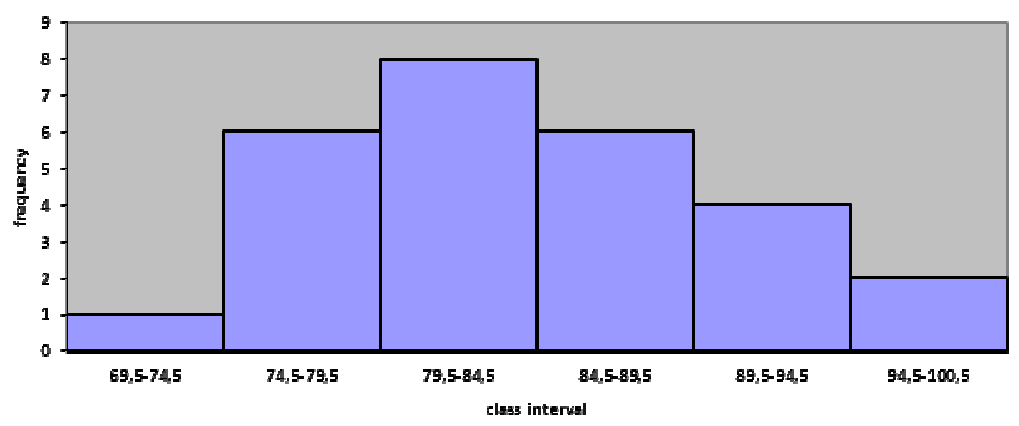

Chart 3. Histogram of Student Learning Outcomes Using Learning Media Pop Up Books and Posters with High Critical Thinking

Based on the posttest frequency distribution data for social studies learning outcomes for students who use pop up books and posters with low critical thinking, the histogram can be stated as follows.

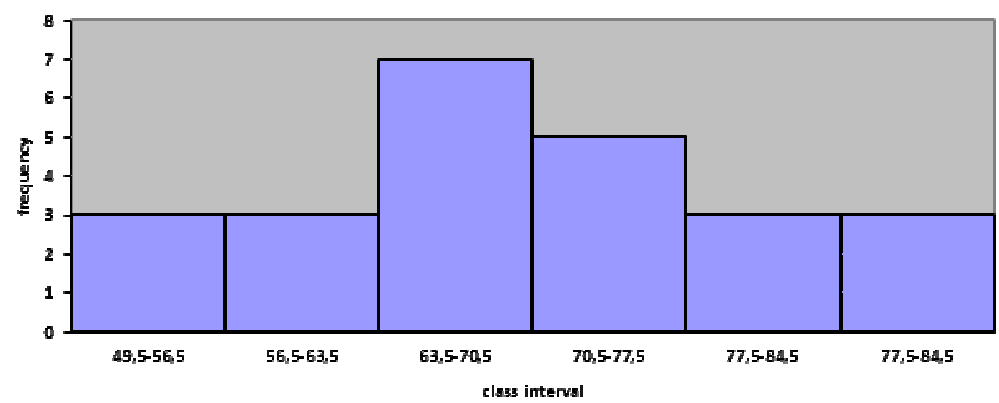

Chart 4. Histogram of Student Learning Outcomes Using Learning Media Pop Up Books and Posters with Low Critical Thinking 
d. Social Studies Learning Outcomes of Students Using Pop Up Book Learning Media based on High Critical Thinking and Low Critical Thinking

Based on the posttest frequency distribution data for social studies learning outcomes students who have high critical thinking can be put forward the following histogram.

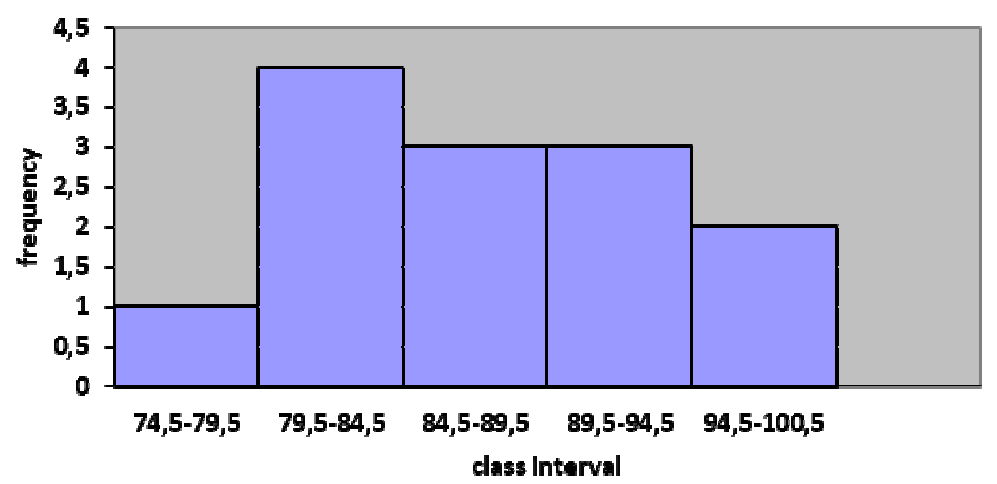

Chart 5. Histogram of Social Studies Learning Outcomes of Students Using Pop up book learning media that has high critical thinking

Based on the posttest frequency distribution data for social studies learning outcomes students who have low critical thinking can be put forward the following histogram.

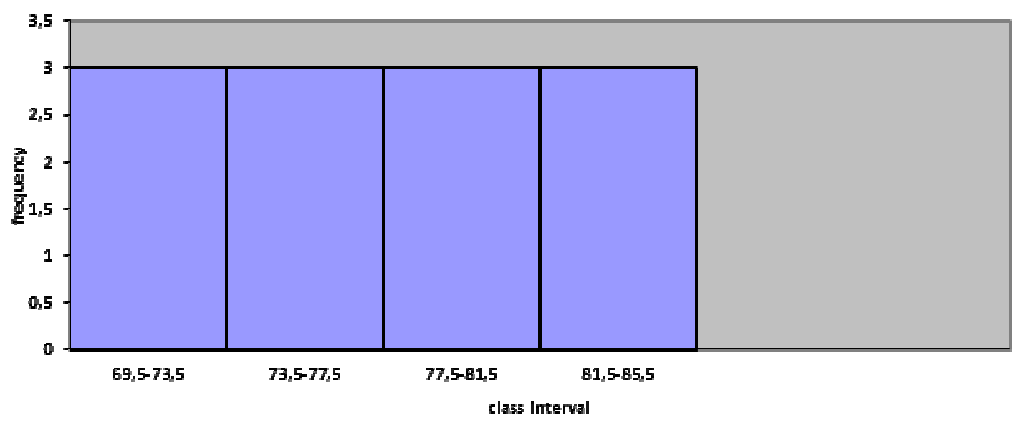

Chart 6. Bag Histogram of Social Studies Learning Outcomes of Students Using Pop up book learning media with low critical thinking [602] 
e. Social Studies Learning Outcomes of Students Using Poster Learning Media Who Have High Critical Thinking and Low Critical Thinking

Student Social Studies learning outcomes Using posters that have high critical thinking, the histogram can be stated as follows.

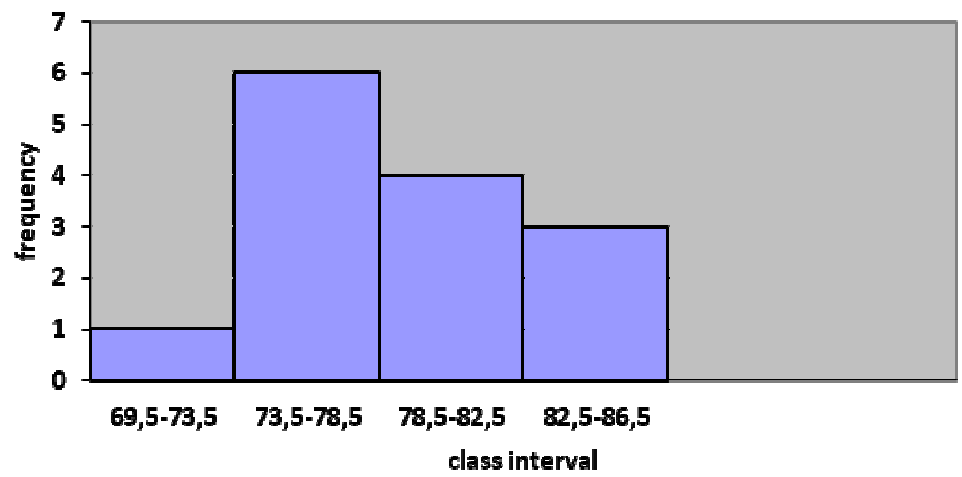

Chart 7. Histogram of Student Learning Results Using Media Learning Poster with High Critical Thinking

Based on the posttest frequency distribution data for social studies learning outcomes students who have low critical thinking can be put forward the following histogram.

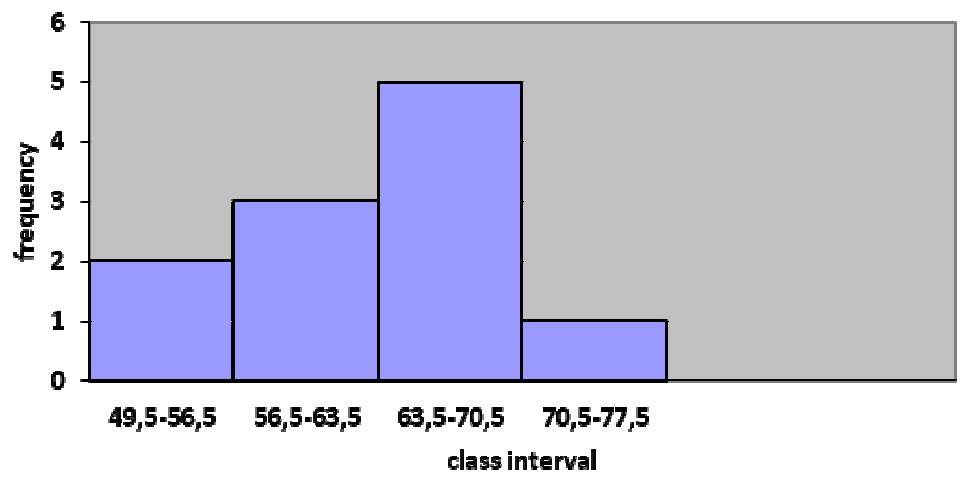

Chart 8. Histogram of Social Studies Learning Outcomes of Students Using Poster Learning Media with Low Critical Thinking 


\section{Testing Requirements Analysis}

Normality test

The results of the normality test of student learning outcomes as a whole can be seen in table 4.12. The normality value with KolgomorovSmirnov is 0.159 with a significance of 0.088 . Because the significance $(0.088)$ is greater than 0.05 , the data is normally distributed.

Table 1. Normality Test Results Learning Outcomes

\begin{tabular}{|c|c|c|c|c|c|c|}
\hline \multicolumn{7}{|c|}{ Tests of Normality } \\
\hline & \multicolumn{3}{|c|}{ Kolmogorov-Smirnova } & \multicolumn{3}{|c|}{ Shapiro-Wilk } \\
\hline & Statisti & df & Sig. & Statisti & df & Sig \\
\hline & CS & & & $\mathrm{CS}$ & & . \\
\hline Learning & 159 & 50 & , 088 & ,954 & 50 & 0.0 \\
\hline outcomes & & & & & & 52 \\
\hline
\end{tabular}

a. Lilliefors Significance Correction

Homogeneity Test

Table 2. Summary of Results of Homogeneity of Variances for Sample

Groups with Levene's Test of Equality Variances

Levene's Test of Equality of Error Variancesa

Dependent Variable: Learning Outcomes

\begin{tabular}{cccc}
\hline$F$ & $d f 1$ & df2 & Sig. \\
\hline 2,661 & 1 & 48 & .109
\end{tabular}

Tests the null hypothesis that the error variance of the dependent variable is equal across groups. 


\section{Hypothesis test}

Based on the results of processing and analysis of research data, it can be stated in Table 4.14 below.

Table 3. 2 × 2 FACTORIAL ANOVA TEST RESULTS

\section{Tests of Between-Subjects Effects}

Dependent Variable:Learning

Outcomes

\begin{tabular}{|c|c|c|c|c|c|}
\hline Source & $\begin{array}{l}\text { Type III } \\
\text { Sum of } \\
\text { Squares }\end{array}$ & $d f$ & $\begin{array}{l}\text { Mean } \\
\text { Square }\end{array}$ & $F$ & Sig. \\
\hline $\begin{array}{l}\text { Corrected Learning } \\
\text { Media }\end{array}$ & $3647353 a$ & 3 & 1215,784 & 29,953 & .000 \\
\hline Intercept & $\begin{array}{r}287256,69 \\
6\end{array}$ & 1 & $\begin{array}{r}287256,6 \\
96\end{array}$ & $\begin{array}{r}7077,0 \\
03\end{array}$ & .000 \\
\hline Learning Media & 1666,157 & 1 & 1666,157 & 41.048 & .000 \\
\hline Think critically & 1836,696 & 1 & 1836,696 & 45,250 & .000 \\
\hline Media * Critical Thinking & 186,157 & 1 & 186,157 & 4,586 & .038 \\
\hline Error & 1867,147 & 46 & 40,590 & & \\
\hline Total & $\begin{array}{r}295075,00 \\
0\end{array}$ & 50 & & & \\
\hline Corrected Total & 5514,500 & 49 & & & \\
\hline
\end{tabular}

a. R Squared $=, 661$ (Adjusted R Squared $=, 639$ ) 


\section{Discussion}

Social Studies learning outcomes of students taught by pop up book media are higher than students social studies learning outcomes taught using poster media

The results of the two-way ANOVA test were decided to reject Ho and accept Ha. This shows that the social studies learning outcomes of students who are taught with pop up book media are higher than those of students who are taught using poster media.

In addition to the nature of the subject matter, one of the other rationale used by teachers as a consideration in determining learning media is the characteristics of students. Uno (2006:143) reveals that the characteristics of students are one of the things that need to be identified by the teacher to be used as a guide in developing learning programs. Each student has different potentials and characteristics. A teacher must try to accommodate the potential of students maximally in the implementation of learning that is applied in the classroom. Student characteristics such as motivation, interests, talents, intelligence, learning styles, personality, emotions, feelings, thoughts, and metacognition need to be considered and integrated in determining the learning media used.

Based on the results of the analysis that has been carried out, the social studies learning outcomes of students taught with pop up book media obtained an average score of 91.2, while the social studies learning outcomes of students taught using poster media obtained an average score of 76.2. Thus, it can be concluded that the social studies learning outcomes of students who were taught using pop up book media were higher than those of students who were taught using poster media. 
Social Studies learning outcomes of students with high critical thinking are higher than social studies learning outcomes of students with low critical thinking

Based on the two-way ANOVA test it was decided to reject Ho and accept Ha. This means that the social studies learning outcomes of students who think critically are higher than those of students who have low critical thinking.

Aeni (2018:4) reminds that critical thinking does not mean harsh, negative, or harsh, but critical thinking is more about thinking carefully, consistently, and precisely. Critical thinking is the basis of higher order thinking. If students have enthusiasm and are motivated to think critically, it will be easier to accept learning.

Based on the results of the analysis that has been carried out, the social studies learning outcomes of students who have high critical thinking get an average score of 82.83 . While the social studies learning outcomes of students who have low critical thinking get an average value of 72.5. From the results of the data analysis shows that on average the social studies learning outcomes of students who have high critical thinking are better than students who have low critical thinking. This indicates that students who have high critical thinking on average have better social studies learning outcomes than students who have low critical thinking. So students who have high critical thinking understand social studies lessons better than students who have low critical thinking.

There is an Interaction Between the Use of Pop Up Books, Posters and Critical Thinking on Students Social Studies Learning Outcomes

Based on the results of the ANOVA test, it was decided to reject Ho and accept $\mathrm{Ha}$. That is, there is an interaction between the use of pop 
up book learning media, posters and critical thinking on students social studies learning outcomes.

Based on the results of the analysis carried out the results of the interaction between the use of pop up book learning media, posters and critical thinking affect students social studies learning outcomes, where students who are taught with pop up book learning media, have higher social studies learning outcomes than students who are taught with learning media poster, then the social studies learning outcomes of students who think critically are higher than the social studies learning outcomes of students who think critically are low. So it can be concluded that there is an interaction between the use of pop up book learning media, posters and critical thinking on students social studies learning outcomes.

\section{Conclusion}

Based on the results of processing and analysis of research data, it can be concluded as follows:

1. Social studies learning outcomes of students taught with pop up book media obtained an average value of 81.8 learning outcomes, while students social studies learning outcomes taught by poster media obtained an average learning outcome score of 70.4. The results of the Anova $2 \times 2$ test are known to have a value of $F=41.048$ with a price of sig $=0.000$, so it can be concluded that the social studies learning outcomes of students taught by pop up book media are higher than those of students who are taught using poster media.

2. Social studies learning outcomes of students who think highly critically get an average value of social studies learning outcomes of 81.92 , while social studies learning outcomes of students with low 
critical thinking get an average value of 69.79 . The results of the Anova $2 \times 2$ test are known to have a value of $F=45.250$ with a price of sig $=0.000$, so it can be concluded that the social studies learning outcomes of students who think critically are higher than those of students who have low critical thinking.

3. The results of the Anova $2 \times 2$ interaction between the use of pop up book learning media, posters and critical thinking on students social studies learning outcomes are known that $F=4,586$ with a price of sig $=0.038$, so it is concluded that there is an interaction between the use of pop up book, poster and critical thinking learning media on students social studies learning outcomes.

\section{Bibliography}

Aeni, dkk. (2018). Pendidikan Nilai Nasionalisme Dengan Media Pop Up Book Untuk Meningkatkan Berpikir Kritis Siswa Kelas V Sekolah Dasar. Jurnal Review Pendidikan Dasar: Jurnal Kajian Pendidikan dan Hasil Penelitian. e-ISSN: 2460-8475. Vol 4, No 3.

Bluemel \& Taylor. (2012). Pop-up Books A Guide For Teachers and Librarians. California: ABC-CLJO. LLC.

Hasan, Said, H. (2014). Kurikulum dan Tujuan Pendidikan, Jurnal JPIS. Bandung: Media Komunikasi Antar FPIPS-UPI, FKIP Universitas/STKIP Se-Indonesia.

Rizki \& Bambang. (2020). Pentingnya Media Dalam Pembelajaran Guna Meningkatkan Hasil Belajar di Sekolah Dasar. Edukatif: Jurnal IImu Pendidikan. Vol 2 No 1. p-ISSN 2656-8063 e-ISSN 2656-8071. Halaman 23- 27. 